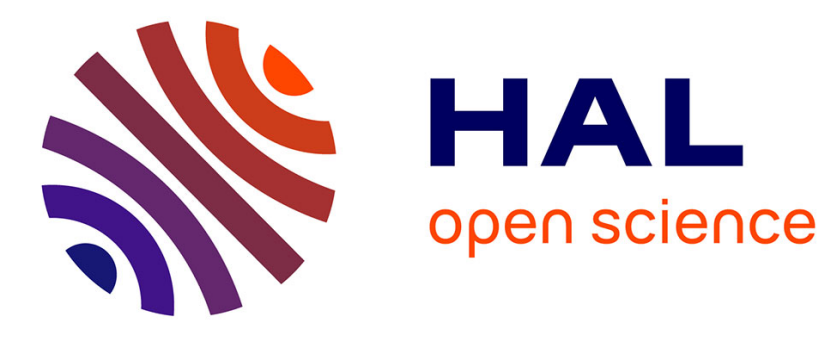

\title{
Damage Factor for Radiation-Induced Dark Current in InGaAs Photodiodes
}

Olivier Gilard, Lip Sun How, Audrey Delbergue, Christophe Inguimbert, Thierry Nuns, Juan Barbero, Juan Moreno, Louis Bouet, Stephane

Mariojouls, Mathieu Boutillier

\section{To cite this version:}

Olivier Gilard, Lip Sun How, Audrey Delbergue, Christophe Inguimbert, Thierry Nuns, et al.. Damage Factor for Radiation-Induced Dark Current in InGaAs Photodiodes. IEEE Transactions on Nuclear Science, 2018, 65 (3), pp.884-895. 10.1109/TNS.2018.2799742 . hal-01883455

\section{HAL Id: hal-01883455 https://hal.science/hal-01883455}

Submitted on 28 Sep 2018

HAL is a multi-disciplinary open access archive for the deposit and dissemination of scientific research documents, whether they are published or not. The documents may come from teaching and research institutions in France or abroad, or from public or private research centers.
L'archive ouverte pluridisciplinaire HAL, est destinée au dépôt et à la diffusion de documents scientifiques de niveau recherche, publiés ou non, émanant des établissements d'enseignement et de recherche français ou étrangers, des laboratoires publics ou privés. 


\title{
Damage Factor for Radiation-Induced Dark Current in InGaAs Photodiodes
}

\author{
Olivier Gilard, Lip Sun How, Audrey Delbergue, Christophe Inguimbert, Thierry Nuns, Juan \\ Barbero, Juan Moreno, Louis Bouet, Stéphane Mariojouls, Mathieu Boutillier
}

\begin{abstract}
In this paper a compendium of InGaAs irradiation test results is presented. These photodiodes were irradiated either with $\gamma$-rays, protons, neutrons, electrons, pions, alpha particles or carbon ions of various energies. The displacement damage dose formalism was found to be effective in describing the radiation-induced dark current increase of any of the studied InGaAs photodiodes. The exploitation of capacitancebias voltage and current-bias voltage measurements also allows to deduce a damage factor that can be used to assess the radiation-induced dark current in a great number of radiation environments.
\end{abstract}

Index Terms - Photodiodes, indium gallium arsenide devices, dark current, displacement damage.

\section{INTRODUCTION}

$\mathbf{I}$ $\mathrm{N}$ the space domain, indium gallium arsenide ( $\mathrm{InGaAs}$ ) photodiodes are of primary interest to address a number of applications dealing with intra- and inter-satellite communications [1], remote sensing [1], imaging [2]-[3], onboard metrology and satellite attitude control [4].

However, when these devices are operated in space their performance can be significantly impacted by the radiation space environment. Indeed, even if these photodiodes are not very sensitive to ionizing effects [5], their dark current is strongly impacted by displacement damage [5], [10]-[14], [16], [17], [19], [20] and [24]. It is therefore of high importance to characterize the behavior of this technology of photodiode with respect to non-ionizing radiation. In this study we analyze the impact of displacement damage on the dark current of various references of photodiode irradiated with different types of particles and for a broad range of energies.

O. Gilard and M. Boutillier are with the French Space Agency CNES, 18 av Edouard Belin, 31401 Toulouse Cedex 4, France (email: olivier.gilard@cnes.fr, mathieu.boutillier@cnes.fr).

L. S. How and A. Delbergue are with AdvEOTec, ZAC Clos Pois, 6 Rue de la Closerie, 91090 Lisses, France (email: lipsunhow@adveotec.com, audreydelbergue@adveotec.com).

C. Inguimbert and T. Nuns are with ONERA-DPhIEE, 31055 Toulouse, France (e-mail: christophe.Inguimbert@onera.fr, thierry.nuns@onera.fr).

J. Barbero and J. Moreno are with ALTER Technology, Madrid, Spain (email:juan.barbero@altertechnology.com, juan.moreno@altertechnology.com ) L. Bouet and S. Mariojouls are with Airbus Defence and Space, 31 Rue des Cosmonautes, 31400 Toulouse, France (email : louis.bouet@airbus.com, stephane.mariojouls@airbus.com)
Based on these data we introduce and characterize a damage factor related to the dark current produced by radiationinduced generation centers in the bulk depleted region. This damage factor, similar to the one defined by J.R. Srour et al. in silicon-based devices [6], can be used to assess the radiationinduced dark current of InGaAs photodiodes in a great number of radiation environments.

\section{TYPICAL PHOTODIODE STRUCTURE}

The ternary alloy $\operatorname{In}_{0.53} \mathrm{Ga}_{0.47}$ As with a band gap of about $0.75 \mathrm{eV}$ is the choice material for detection in the $1.3-1.55 \mu \mathrm{m}$ range. It is perfectly lattice matched to indium phosphide (InP) which is used as substrate material. As shown in Fig. 1 a typical planar InGaAs/InP photodiode consists of a lightly Ndoped InGaAs absorption layer deposited on top of the N-type InP substrate. An InP cap layer is grown on the absorber. The $\mathrm{P}-\mathrm{N}$ junction is obtained by diffusion of P-type dopant zinc atoms through the cap layer and up to the absorption layer. Due to its high absorption coefficient in the near infrared region, the InGaAs layer is typically a few micrometers thick which is convenient to achieve full depletion at relatively low reverse bias voltage, generally between to 2 to $5 \mathrm{~V}$. The structure of the various photodiodes studied in this paper is not known in detail but is believed to be similar to the one shown in Fig. 1.

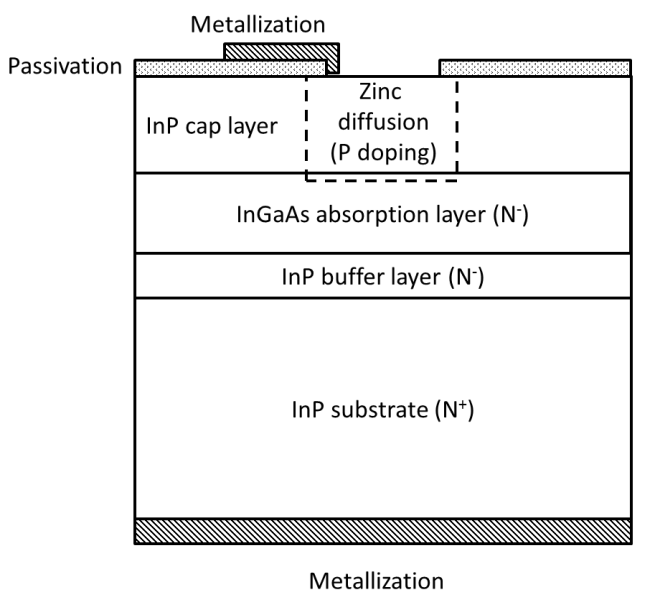

Fig. 1. Schematic cross-section of a typical planar InGaAs/InP photodiode.

In this paper we report new irradiation tests results obtained 
on commercial off-the-shelf InGaAs photodiodes and we compare these results with data found in the literature.

\section{IRRADIATION TEST RESULTS}

\section{A. Irradiation test conditions}

The tables given in the Appendixes summarize the irradiation conditions for the photodiodes tested in this study (Appendix I) or whose sensitivity to radiation has been already characterized elsewhere (Appendix II). These photodiodes were irradiated either with $\gamma$-rays, protons, neutrons, electrons, pions, alpha particles or carbon ions of various energies.

\section{B. Dark current measurements}

The dark current was measured before and after irradiation. Unless indicated in the tables in the Appendixes, the measurements were made at room temperature and for a reverse bias of $5 \mathrm{~V}$. All the available information regarding the irradiation and the measurement conditions are also reported in these tables.

In Fig. 2 the variation of the dark current density, i.e., dark current increase divided by the photosensitive area, is plotted as a function of the displacement damage dose defined as the product of the Non Ionizing Energy Loss (NIEL) by the particle fluence. Figure 2 (a) shows the new results obtained in this study while Fig. 2 (b) gives an overview of the full data set reported in Appendixes I and II.

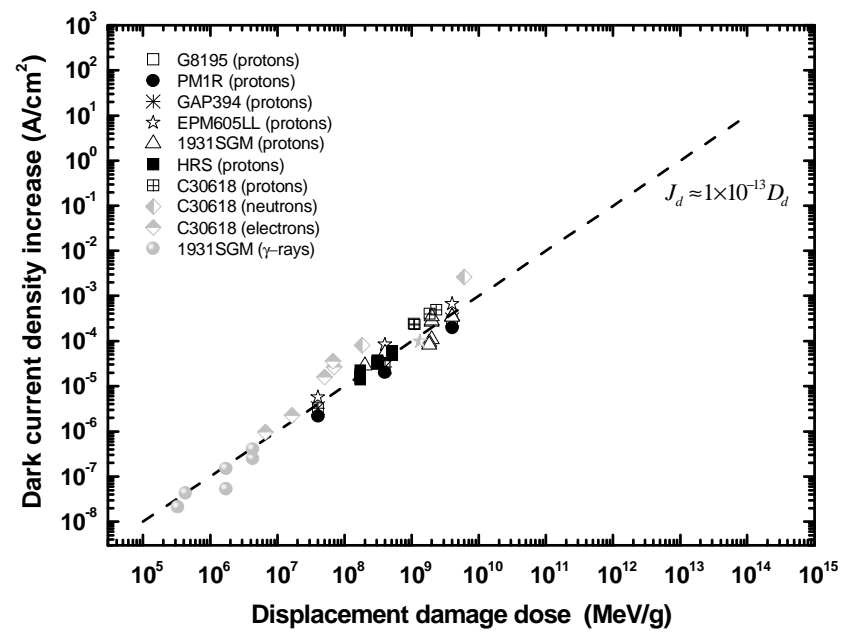

(a)

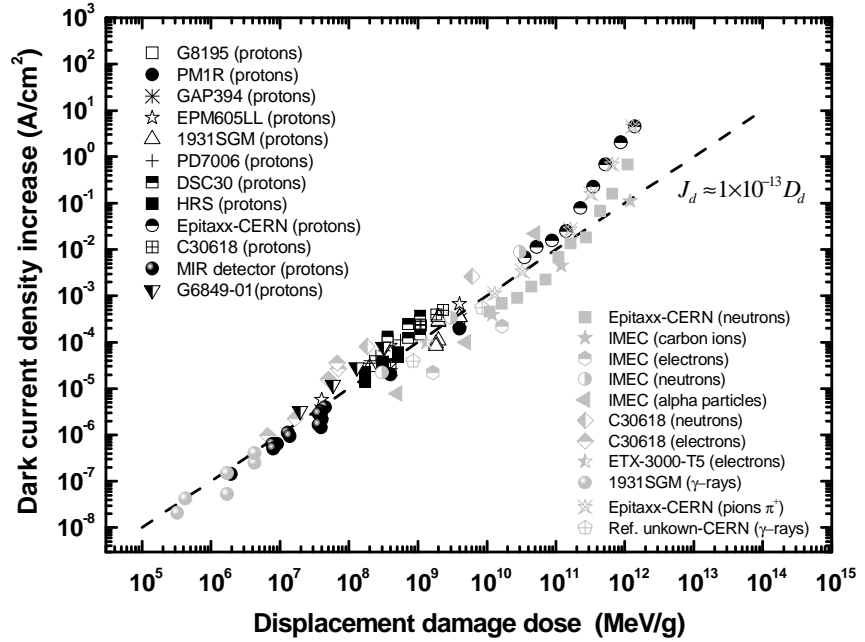

(b)

Fig. 2. Dark current density increase as a function of the displacement damage dose. Figure 2 (a) shows the results obtained in this work while Figure 2 (b) also includes the data from the literature. The dark current was measured at a reverse bias of $-5 \mathrm{~V}$ unless otherwise mentioned in the Appendixes. The dashed line, shown as a guide to the eye, has a slope equal to 1 in this $\log -\log$ plot. The dark current density before irradiation ranges between $10^{-8}$ and $10^{-7} \mathrm{~A} / \mathrm{cm}^{2}$.

\section{NIEL calculations}

The NIEL values used to calculate the displacement damage dose deposited in the $\operatorname{In}_{0.53} \mathrm{Ga}{ }_{0.47} \mathrm{As}$ active region are also shown in the Appendixes. Most of them have been computed using the SR-NIEL [7] code and the NEMO [8] package of OMERE [9]. For SR-NIEL calculations the threshold energy value implemented by default in the calculator, i.e., $21 \mathrm{eV}$, has been selected for $\mathrm{Ga}$, As and In. Regarding the NEMO computations, a threshold energy of $10 \mathrm{eV}$ was preferred for both $\mathrm{Ga}$ and As while for In a threshold of $15 \mathrm{eV}$ was retained. The spread in the NIEL values calculated under different assumptions with two distinct codes gives an indication of the uncertainty attached to this parameter. With a few exceptions pointed out in the Appendixes, the NIEL values calculated with NEMO were used to plot the data in Fig. 2.

The Compton electrons scattered during the interaction of $\gamma$ rays with matter can also induce displacement damage. The displacement damage dose generated by these Compton electrons was calculated using a NIEL value provided in [21]. In this reference the NIEL of ${ }^{60} \mathrm{Co} \gamma$-rays have been calculated for GaAs. Using a threshold displacement energy of $10 \mathrm{eV}$ for both Ga and As, El Allam et al. found a NIEL value for GaAs of $8.53 \times 10^{-8} \mathrm{MeV} . \mathrm{cm}^{2} / \mathrm{g}$ which is also close to the values given in [22] for GaAs, $\left(9.7 \times 10^{-8} \mathrm{MeV} . \mathrm{cm}^{2} / \mathrm{g}\right)$ and $\mathrm{Si}\left(1.07 \times 10^{-7}\right.$ $\mathrm{MeV} . \mathrm{cm}^{2} / \mathrm{g}$ ). Since $\gamma$-rays NIEL values in InGaAs compounds have not yet been published, the GaAs NIEL was used to plot the data in Fig. 2 even if it can lead to a source of uncertainty. To calculate the displacement damage dose deposited by $\gamma$ rays, their fluence also needs to be known. The $\gamma$-rays fluence $\Phi$ was assessed using 


$$
\Phi=\frac{D}{E \frac{\mu}{\rho}}
$$

where $D$ is the ionizing dose $(\mathrm{MeV} / \mathrm{g}), E$ the energy per photon $(\mathrm{MeV})$, and $\frac{\mu}{\rho}$ the mass attenuation coefficient at the energy $E$ expressed in $\mathrm{cm}^{2} / \mathrm{g}$.

The value of the mass attenuation coefficient depends on the nature of the irradiated material and the energy of the photons. Nevertheless, mass attenuation coefficients are very similar for a wide range of materials. For the $\gamma$-rays emitted at 1.17 and $1.33 \mathrm{MeV}$ from a ${ }^{60} \mathrm{Co}$ source a value of about $0.05 \mathrm{~cm}^{2} / \mathrm{g}$ can be used [23].

A damage factor of about $1 \times 10^{-13}$ was determined from Fig. 2 assuming a linear relationship. Although deviations are observed by nearly a factor of 10 in some cases, there is still good agreement over more than 6 orders of magnitude regardless of the actual photodiode or the nature of the incident particles. This consistency in the results suggests that the same dark current generation mechanism is working over the entire range of dose.

It is also worth noting that above $10^{11} \mathrm{MeV} / \mathrm{g}$ for very high displacement damage doses, the dark current increase tends to become non-linear. The deviations from linearity are either related to the formation of defect clusters affecting the dark current increase or due to carrier removal.

\section{Dark current sources}

To characterize the defects at the origin of the dark current increase in the linear degradation regime, 5 photodiode references from the ones listed in the Appendixes have been characterized at different temperatures ranging from $-10^{\circ} \mathrm{C}$ to $70^{\circ} \mathrm{C}$ before and after proton exposure. For each of these devices, the activation energy related to dark current has been extracted. Its variation with respect to the displacement damage dose is shown in Fig. 3.

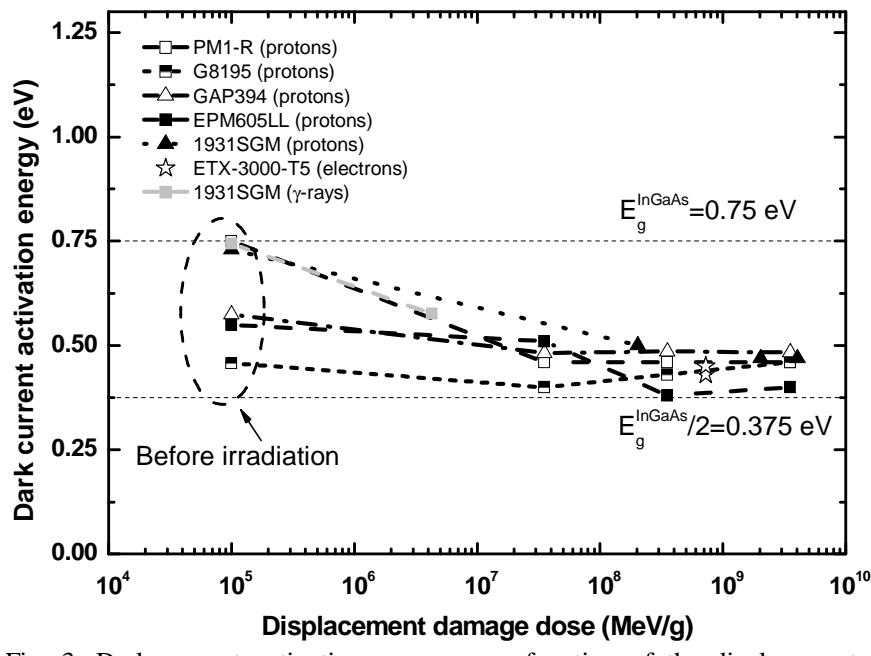

Fig. 3. Dark current activation energy as a function of the displacement damage dose. Because of the log scale, displacement damage dose of $10^{5}$
$\mathrm{MeV} / \mathrm{g}$ corresponds in reality to pre-irradiation results. The pre-irradiation dark current was not subtracted from the current measured after irradiation.

Overall, we observe a decrease in the activation energy with the displacement damage dose. For 3 references out of 5, the impact of radiation is rather small, with an energy value close to the $\mathrm{In}_{0.53} \mathrm{Ga}_{0.47}$ As midgap energy whether it be before or after irradiation. Such a small value indicates that the dark current is likely dominated by generation-recombination mechanism in the depleted absorber region.

For the two other devices, the activation energy prior irradiation is close to the $\mathrm{In}_{0.53} \mathrm{Ga}_{0.47} \mathrm{As}$ bandgap value meaning that the dark current is, in this case, diffusion limited. The subsequent introduction during irradiation of recombination centers tends to enhance the generation-recombination current and therefore to decrease the value of the activation energy to a value close to midgap.

As shown in Fig. 3, the results obtained on proton irradiated devices are fully consistent with those reported in [20] after electron irradiations. Indeed after a $1 \mathrm{MeV}$ electron exposure, the activation energy of ETX-3000-T5 photodiodes from Epitaxx was found to range between 0.43 and $0.45 \mathrm{eV}$ in close agreement with our results. Deep Level Transient Spectroscopy measurements also carried out in [20] reveal the presence of a defect in the InGaAs layer, labeled E2, located at $0.46 \mathrm{eV}$ from the valence band edge. This energy value agrees well with the dark current activation energies. Even if the nature of the E2 defect is not known, the authors in [20] mention that it could be related to a relatively simple As vacancy/impurity complex.

Finally, to complete the picture we also add in Fig. 3 the results obtained after the irradiation with $\gamma$-rays of a 1931 SGM photodiode from 3SPhotonics. This device was characterized at $0^{\circ} \mathrm{C}, 25^{\circ} \mathrm{C}$ and $70^{\circ} \mathrm{C}$ before and after a 50 krad irradiation. Here again we observe a decrease in the dark current activation energy which is consistent with the trend previously noted.

\section{E. NIEL scaling}

The linear relationship between the dark current density increase and the displacement damage dose shown in Fig. 2 seems to confirm the relevance of the underlying NIEL scaling hypothesis. To validate this assumption, the NIEL spectra for protons, electrons and neutrons have been plotted and scaled with the dark current density per unit of fluence. Results are shown in Fig. 4. 


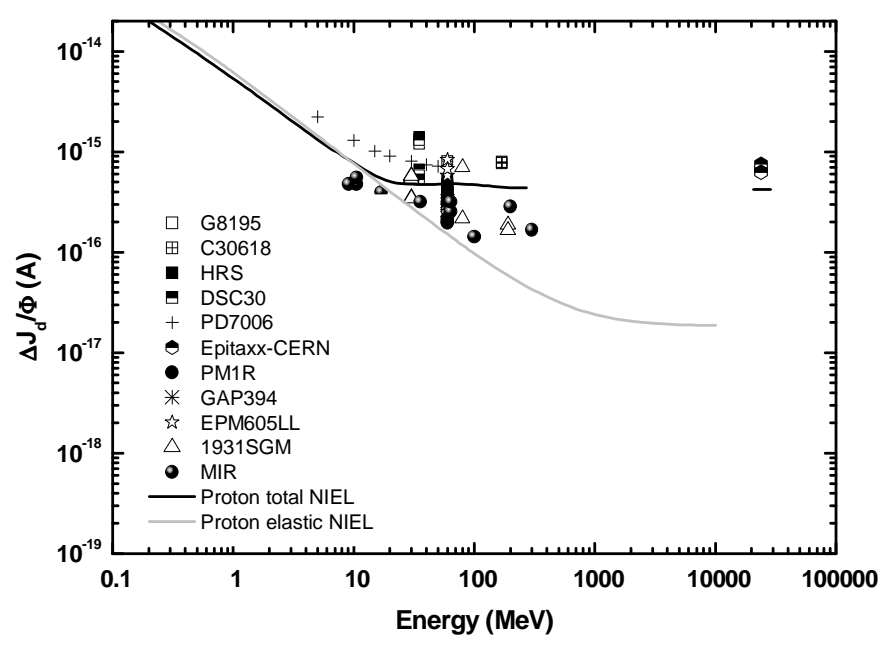

(a)

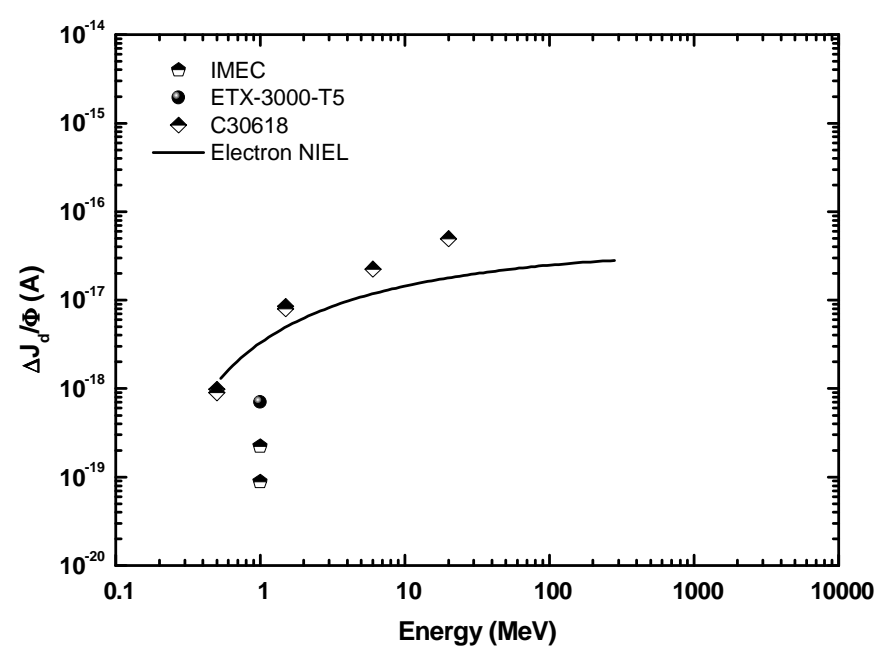

(b)

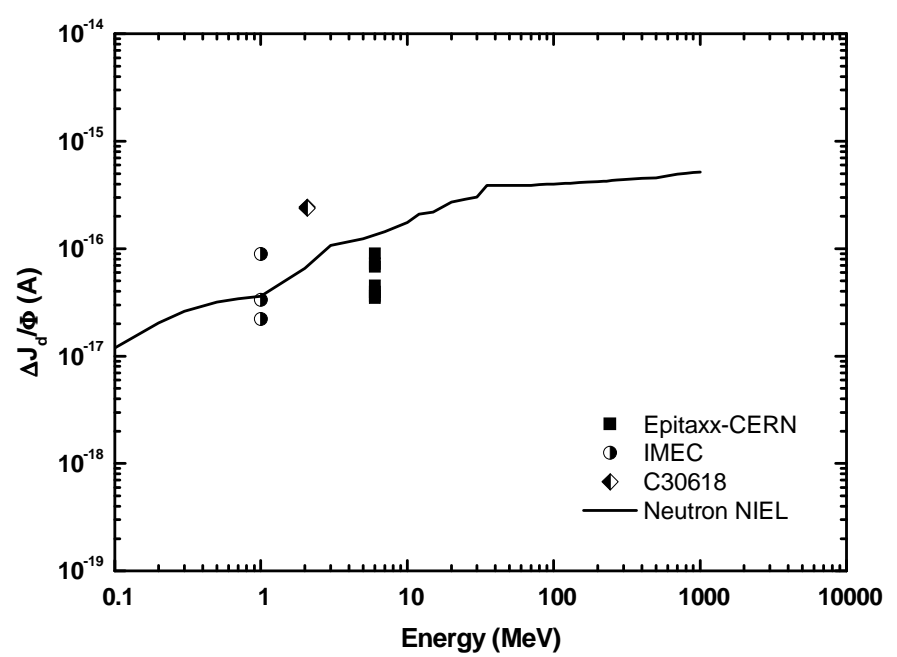

(c)

Fig. 4. Relative comparison between NIEL spectra and dark current density increase per unit of fluence for proton (a), electron (b) and neutron (c) irradiated devices. The NIEL spectra were roughly scaled to be in close proximity to the measured data. The scaling factors are $1.2 \times 10^{-13}$ for proton and neutron data and $2 \times 10^{-13}$ for electron data. Note that in Figure 4 (a) the data at the far right of the plot correspond to the results from CERN obtained on an Epitaxx photodiode after a $23 \mathrm{GeV}$ proton irradiation [16]. As far as possible the total NIEL spectra were calculated with NEMO. The SR-NIEL code was used to calculate the elastic part of the proton NIEL. The data corresponding to the non-linear regime shown in Fig. 2 i.e. $>10^{11} \mathrm{MeV} / \mathrm{g}$, have not been reported in these figures.

At first sight, the correlation between the measurements and the NIEL seems to be confirmed. For proton irradiated photodiodes, the change in the slope of the curve at several tens of $\mathrm{MeV}$ (Fig. 4(a)) seems to be correlated to the total NIEL rather than with the elastic NIEL. However, this conclusion based on the relative comparison between the NIEL and the damage factor needs to be tempered by the fact that only few devices have been irradiated with a full set of particles (electron, proton, and neutron) on a wide energy range. The relative comparison of the damage factor of electrons and protons measured on an identical component is the only way to check accurately the reliability of the NIEL scaling approach. Regarding electrons and neutrons, quite large differences in the data are observed within a given energy range, and even if it seems that the NIEL scaling approach can be used, additional data would be necessary to confirm this presupposition.

\section{DARK CURRENT DAMAGE FACTOR}

Hereupon it is of interest to quantify the impact of displacement damage on InGaAs photodiodes by introducing a damage factor able to describe the generation mechanism responsible for the dark current increase. The most appropriate formalism to do that has been proposed by J.R. Srour et al. for silicon-based devices in [6]. Following the same approach, we have

$$
\Delta J_{d}=q W D_{d} K_{d a r k}
$$

where $\Delta J_{d}$ is the dark current density increase, $q$ the electronic charge, $W$ the depletion region width in the absorber, $D_{d}$ the displacement damage dose and $K_{\text {dark }}$ the dark current damage factor.

This equation assumes that the dark current density increase is related to generation processes in the depleted InGaAs layer which is supported by the results given in Section III.D.

To determine $K_{\text {dark }}$, capacitance-bias voltage (CV) and current-bias voltage (IV) measurements were performed on 5 photodiode references irradiated either with protons or with $\gamma$ rays.

The capacitance $C$ of a photodiode is given by

$$
C=C_{j}+C_{p}
$$

where $C_{j}$ and $C_{p}$ are the junction and package capacitance respectively. 
We have

$C=\frac{\varepsilon A}{W}+C_{p}$

where $\varepsilon$ is the permittivity of InGaAs and $A$ the junction area.

Combining Eq. (2) and (4), we get

$\Delta J_{d}=q \frac{\varepsilon A}{C-C_{p}} D_{d} K_{d a r k}$

and therefore

$\frac{D_{d}}{\Delta J_{d}}=\frac{C}{q \varepsilon A K_{\text {dark }}}-\frac{C_{p}}{q \varepsilon A K_{\text {dark }}}$

The parameter $\frac{D_{d}}{\Delta J_{d}}$ is plotted in Fig. 5 as a function of $\frac{C}{q \varepsilon A}$ for the 5 photodiodes.

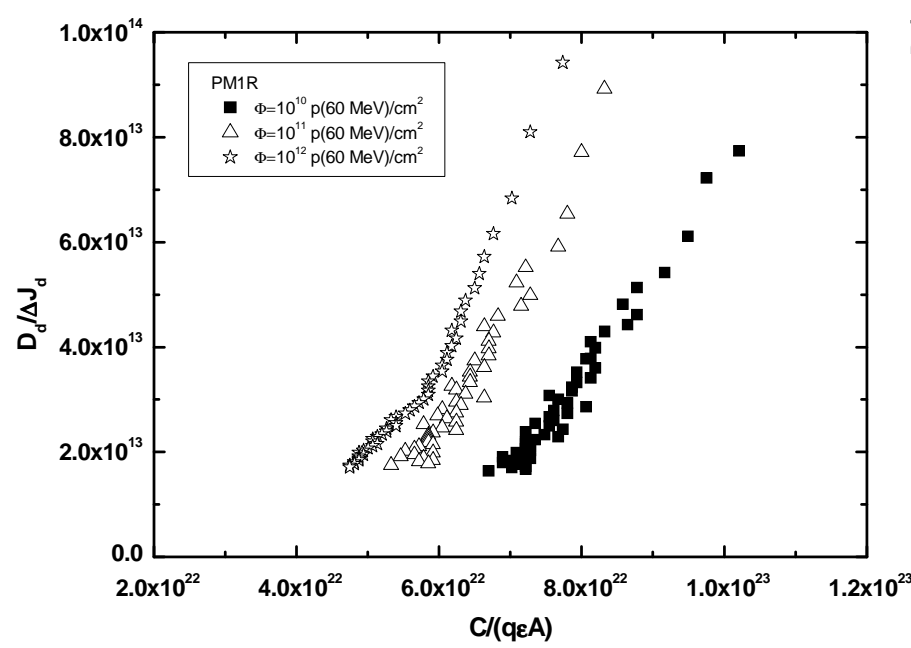

(a)

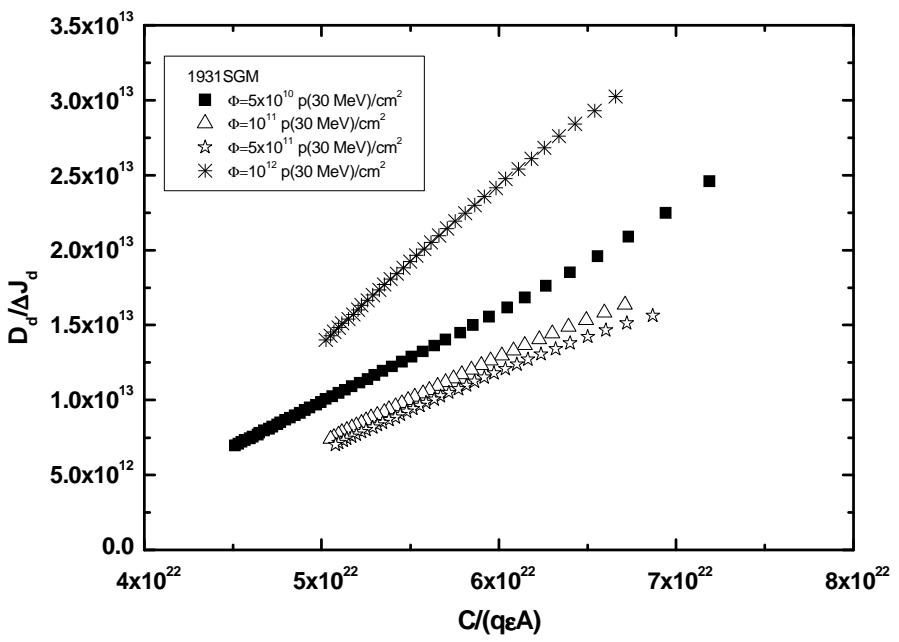

(b)

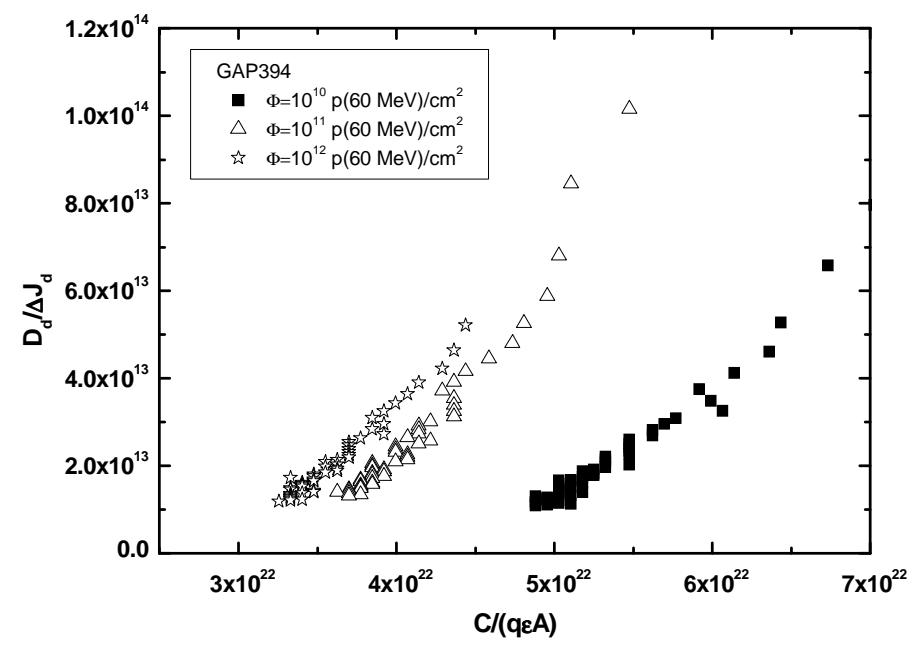

(c)

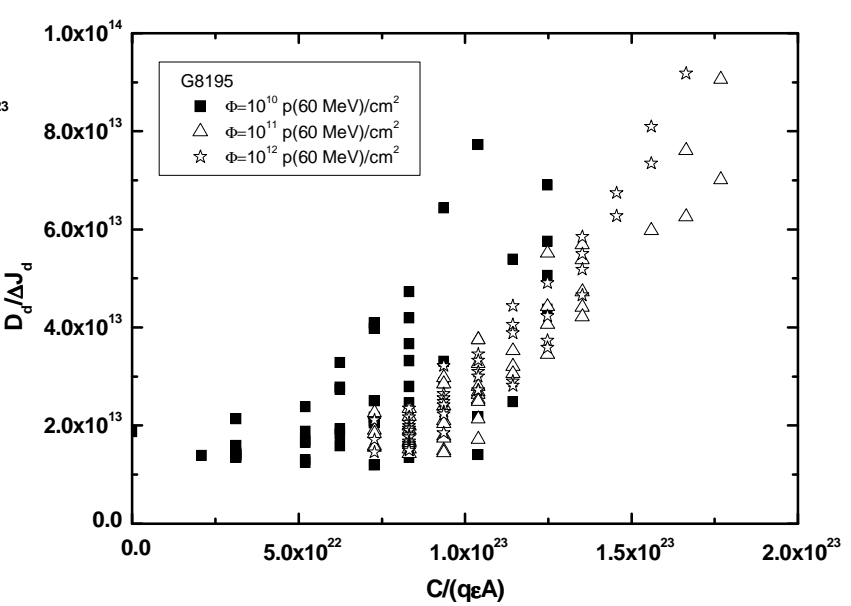

(d) 


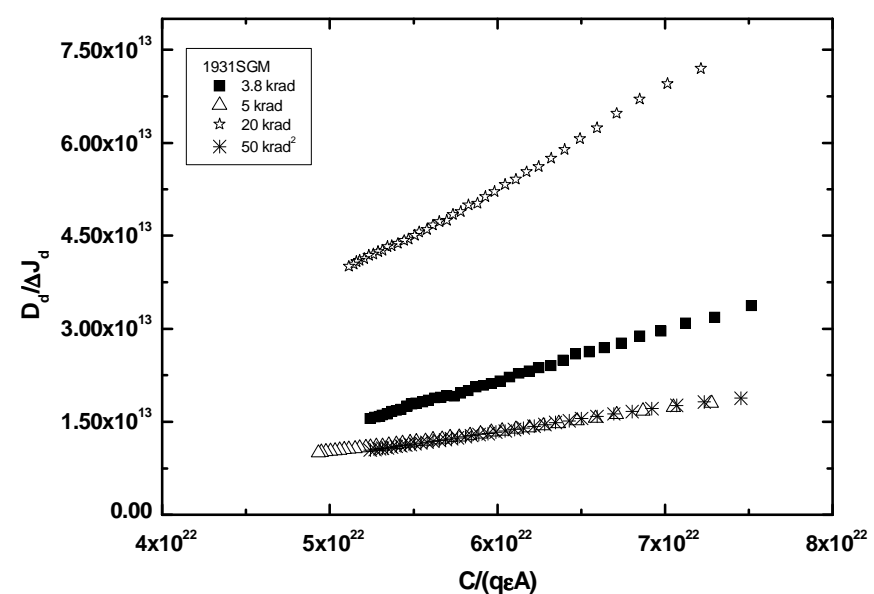

(e)

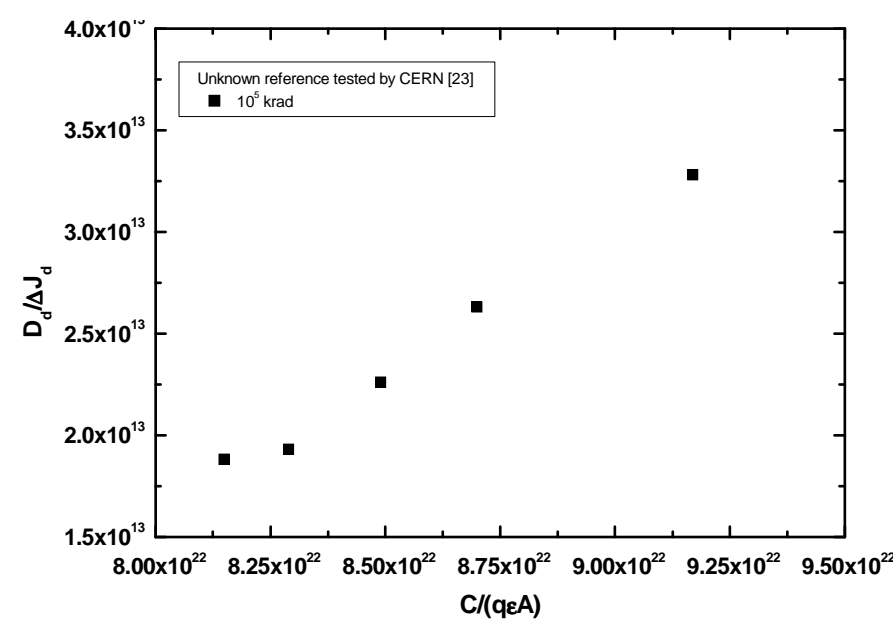

(f)

Fig. 5. $\frac{D_{d}}{\Delta J_{d}}$ versus $\frac{C}{q \varepsilon A}$ for proton irradiated PM1R (a), 1931SGM (b), GAP394 (c) and G8195 (d) photodiodes. Figure (e) gives the results obtained on 1931SGM photodiodes irradiated with $\gamma$-rays. In figure (f) the data given in [24] have been reported for an InGaAs photodiode (unknown reference) irradiated by CERN also with $\gamma$-rays. IV and CV were measured at room temperature. The capacitance was measured at a frequency of $1 \mathrm{MHz}$. The scattered results obtained on photodiodes G8195 are related to the capacitance measurements. Indeed, due to its relative small sensitive area, this reference features a capacitance about $1 \mathrm{pF}$ at the limit of the capacitance meter resolution.

The linear trend observed in Fig. 5 confirms that Eq. (6) is relevant to explain the dark current increase after irradiation. For each irradiated step, $K_{d a r k}$ and $C_{p}$ have been extracted from these plots by calculating the slope and the intercept of the best linear fit. The outcomes are given in Table I.

Table I : $K_{\text {dark }}$ and $C_{p}$ extracted from the plots given in Fig. 5.

\begin{tabular}{|l|l|l|l|l|}
\hline PM1R & $\begin{array}{l}\text { Fluence } \\
\left(\mathrm{p} / \mathrm{cm}^{2}\right)\end{array}$ & $\begin{array}{l}\text { Energy } \\
(\mathrm{MeV})\end{array}$ & $\mathrm{K}_{\text {dark }}\left(\mathrm{cm}^{-3} \mathrm{~s}^{-1} \mathrm{MeV} \mathrm{g}^{-1}\right)$ & $\mathrm{C}_{\mathrm{p}}(\mathrm{F})$ \\
\hline & $1 \times 10^{10}$ & 60 & $4.83 \times 10^{8}$ & $9.38 \times 10^{-12}$ \\
\cline { 2 - 5 } & $1 \times 10^{11}$ & 60 & $3.87 \times 10^{8}$ & $7.52 \times 10^{-12}$ \\
\cline { 2 - 5 } & $1 \times 10^{12}$ & 60 & $3.91 \times 10^{8}$ & $6.46 \times 10^{-12}$ \\
\cline { 2 - 5 }
\end{tabular}

\begin{tabular}{|c|c|c|c|c|}
\hline \multirow{5}{*}{$\begin{array}{l}\text { 1931SG } \\
\begin{array}{l}\text { M } \\
\text { protons }\end{array}\end{array}$} & $\begin{array}{l}\text { Fluence } \\
\left(\mathrm{p} / \mathrm{cm}^{2}\right)\end{array}$ & $\begin{array}{l}\text { Energy } \\
(\mathrm{MeV})\end{array}$ & $\mathrm{K}_{\text {dark }}\left(\mathrm{cm}^{-3} \mathrm{~s}^{-1} \mathrm{MeV} \mathrm{g}^{-1}\right)$ & $\mathrm{C}_{\mathrm{p}}(\mathrm{F})$ \\
\hline & $5 \times 10^{10}$ & 30 & $1.59 \times 10^{9}$ & $4.36 \times 10^{-12}$ \\
\hline & $1 \times 10^{11}$ & 30 & $1.82 \times 10^{9}$ & $4.01 \times 10^{-12}$ \\
\hline & $5 \times 10^{11}$ & 30 & $2.02 \times 10^{9}$ & $3.97 \times 10^{-12}$ \\
\hline & $1 \times 10^{12}$ & 30 & $9.86 \times 10^{8}$ & $3.96 \times 10^{-12}$ \\
\hline \multirow[t]{5}{*}{$\begin{array}{l}1931 \mathrm{SGM} \\
-\gamma \text {-rays }\end{array}$} & $\begin{array}{l}\text { Fluence } \\
\left(\mathrm{p} / \mathrm{cm}^{2}\right)\end{array}$ & $\begin{array}{l}\text { Dose } \\
\text { (krad) }\end{array}$ & $\mathrm{K}_{\text {dark }}\left(\mathrm{cm}^{-3} \mathrm{~s}^{-1} \mathrm{MeV} \mathrm{g}^{-1}\right)$ & $\mathrm{C}_{\mathrm{p}}(\mathrm{F})$ \\
\hline & $3.8 \times 10^{12}$ & 3.8 & $1.24 \times 10^{9}$ & $3.63 \times 10^{-12}$ \\
\hline & $5 \times 10^{12}$ & 5 & $2.92 \times 10^{9}$ & $2.25 \times 10^{-12}$ \\
\hline & $2 \times 10^{13}$ & 20 & $6.51 \times 10^{8}$ & $2.80 \times 10^{-12}$ \\
\hline & $5 \times 10^{13}$ & 50 & $2.53 \times 10^{9}$ & $2.85 \times 10^{-12}$ \\
\hline
\end{tabular}

\begin{tabular}{|l|l|l|l|l|}
\hline GAP394 & $\begin{array}{l}\text { Fluence } \\
\left(\mathrm{p} / \mathrm{cm}^{2}\right)\end{array}$ & $\begin{array}{l}\text { Energy } \\
(\mathrm{MeV})\end{array}$ & $\mathrm{K}_{\text {dark }}\left(\mathrm{cm}^{-3} \mathrm{~s}^{-1} \mathrm{MeV} \mathrm{g}^{-1}\right)$ & $\mathrm{C}_{\mathrm{p}}(\mathrm{F})$ \\
\hline & $1 \times 10^{10}$ & 60 & $3.19 \times 10^{8}$ & $6.17 \times 10^{-12}$ \\
\cline { 2 - 5 } & $1 \times 10^{11}$ & 60 & $2.06 \times 10^{8}$ & $4.67 \times 10^{-12}$ \\
\cline { 2 - 5 } & $1 \times 10^{12}$ & 60 & $2.93 \times 10^{8}$ & $3.93 \times 10^{-12}$ \\
\cline { 2 - 4 }
\end{tabular}

\begin{tabular}{|l|l|l|l|l|}
\hline G8195 & $\begin{array}{l}\text { Fluence } \\
\left(\mathrm{p} / \mathrm{cm}^{2}\right)\end{array}$ & $\begin{array}{l}\text { Energy } \\
(\mathrm{MeV})\end{array}$ & $\mathrm{K}_{\text {dark }}\left(\mathrm{cm}^{-3} \mathrm{~s}^{-1} \mathrm{MeV} \mathrm{g}^{-1}\right)$ & $\mathrm{C}_{\mathrm{p}}(\mathrm{F})$ \\
\hline & $1 \times 10^{10}$ & 60 & $1.67 \times 10^{9}$ & $1.76 \times 10^{-13}$ \\
\cline { 2 - 5 } & $1 \times 10^{11}$ & 60 & $1.47 \times 10^{9}$ & $5.70 \times 10^{-13}$ \\
\cline { 2 - 5 } & $1 \times 10^{12}$ & 60 & $1.22 \times 10^{9}$ & $6.11 \times 10^{-13}$ \\
\cline { 2 - 4 }
\end{tabular}

\begin{tabular}{|l|l|l|l|l|}
\hline $\begin{array}{l}\text { Unkown } \\
\text { ref. } \\
(\text { CERN }) \\
{[20]}\end{array}$ & $\begin{array}{l}\text { Fluence } \\
(\mathrm{p} / \mathrm{cm} 2)\end{array}$ & $\begin{array}{l}\text { Dose } \\
(\mathrm{krad})\end{array}$ & $\mathrm{K}_{\mathrm{d}}\left(\mathrm{cm}^{-3} \mathrm{~s}^{-1} \mathrm{MeVg}^{-1}\right)$ & $\mathrm{C}_{\mathrm{p}}(\mathrm{F})$ \\
\hline & $1 \times 10^{16}$ & 100000 & $6.94 \times 10^{8}$ & $5.08 \times 10^{-13}$ \\
\hline
\end{tabular}

To validate the extraction methodology for $K_{\text {dark }}$, two $1 \mathrm{~cm}^{2}$ S1337-1010 silicon photodiodes from Hamamatsu have been irradiated with 60 and $100 \mathrm{MeV}$ protons up to a fluence of $1 \times 10^{11} \mathrm{p} / \mathrm{cm}^{2}$. IV and CV measurements were carried out. The associated $\frac{D_{d}}{\Delta J_{d}}$ versus $\frac{C}{q \varepsilon A}$ plot is given in Fig. 6 .

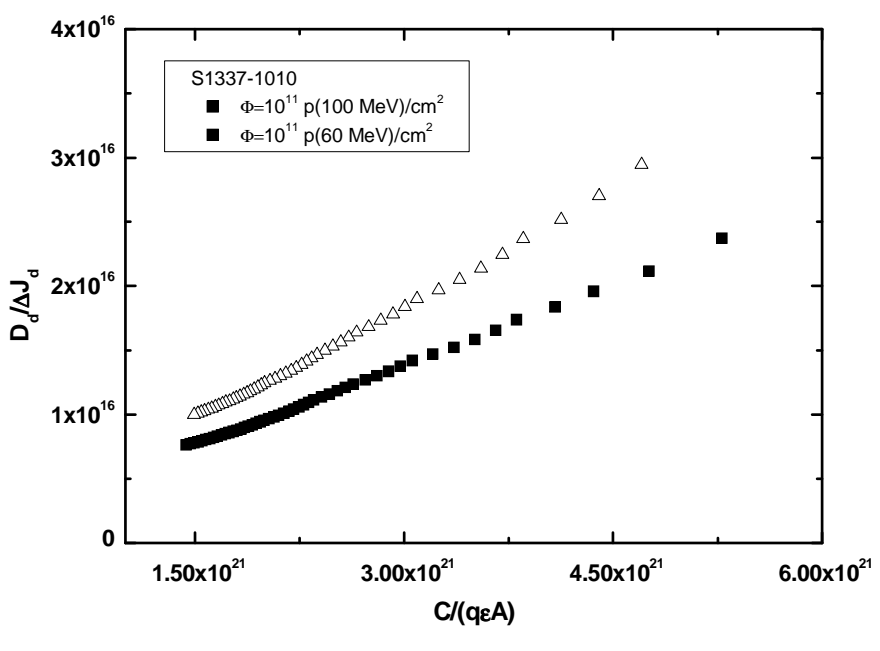


Fig. 6. $\frac{D_{d}}{\Delta J_{d}}$ versus $\frac{C}{q \varepsilon A}$ for the S1337-1010 silicon photodiode from Hamamatsu.

The damage factor calculated after linear regression modeling was found to be equal to $1.69 \times 10^{5}$ and $2.39 \times 10^{5} \mathrm{~cm}^{-}$ ${ }^{3} \mathrm{~s}^{-1} \mathrm{MeVg}^{-1}$ for the 60 and the $100 \mathrm{MeV}$ proton-irradiated photodiodes respectively. These values are in good agreement with those given in [6] for silicon-based detectors ( $\left.K_{\text {dark }, S i}=(1.9 \pm 0.6) \times 10^{5} \mathrm{~cm}^{-3} \mathrm{~s}^{-1} \mathrm{MeVg}^{-1}\right)$.

Furthermore, it is obviously of great interest to check whether the InGaAs damage factor calculated for protons and $\gamma$-rays is also valid for other types of particles. To do so, we considered the data obtained from $1-\mathrm{MeV}$ electron irradiations carried out on ETX-3000-T5 photodiodes from Epitaxx [20]. For a fluence of $8 \times 10^{13} \mathrm{~cm}^{-2}$ and a reverse bias of $5 \mathrm{~V}$, the dark current density increase was $5.6 \times 10^{-5} \mathrm{~A} / \mathrm{cm}^{2}$. CV measurements done prior irradiation allow deducing the doping concentration in the InGaAs layer $\left(N_{D} \approx 2 \times 10^{15} \mathrm{~cm}^{-}\right.$ $\left.{ }^{3}\right)$ as well as the junction built-in voltage $\left(V_{b i} \approx 0.3 \mathrm{~V}\right)$. Therefore it is possible to calculate the depletion width $W$. We have

$$
W=\sqrt{\frac{2 \varepsilon}{q N_{D}}\left(V+V_{b i}\right)}
$$

For a reverse bias of $5 \mathrm{~V}$ we obtain $W \approx 2 \mu \mathrm{m}$. Hence, using Eq. (2) we get $K_{\text {dark }}=1.34 \times 10^{9} \mathrm{~cm}^{-3} \mathrm{~s}^{-1} \mathrm{MeVg}^{-1}$ which is consistent with the values previously obtained from proton and $\gamma$-rays irradiations.

Finally, a mean value of the damage factor can be calculated together with a standard deviation. We found $K_{\text {dark }}=(1.2 \pm 0.8) \times 10^{9} \mathrm{~cm}^{-3} \mathrm{~s}^{-1} \mathrm{MeVg}^{-1}$.

To assess the confidence interval for the mean we used the Bootstrap method proposed by B. Efron [25]. This statistical method based on data resampling with replacement, can be used to estimate confidence intervals of a population parameter like a mean value when the statistic's distribution is unknown which is the case here. The 19 values of $K_{\text {dark }}$ previously determined constitute the initial dataset that was resampled 1000 times. For each new sample a mean value was calculated and the $95 \%$ confidence interval of the mean was deduced. We found $8.32 \times 10^{8} \mathrm{~cm}^{-3} \mathrm{~s}^{-1} \mathrm{MeVg}^{-}$ ${ }^{1} \leq\left\langle K_{\text {dark }}\right\rangle \leq 1.53 \times 10^{9} \mathrm{~cm}^{-3} \mathrm{~s}^{-1} \mathrm{MeVg}^{-1}$.

Despite the relatively large uncertainty associated with the estimated value of $K_{\text {dark }}$, it is worth emphasizing that the sensitivity to displacement damage of InGaAs photodiodes is about three orders of magnitude higher than that of silicon photodiodes. One can also point out that in InGaAs the NIEL scaling holds for high energetic particles to low energetic electrons or $\gamma$-rays irradiation which is not the case in silicon.

\section{CONCLUSION}

A compendium of InGaAs photodiode irradiation test results has been presented. The data either obtained in this study or already published in the literature, show that, regardless of the nature of the irradiation and the photodiode design, the dark current density increases linearly with the displacement damage dose following the same trend over more than 6 decades of dose.

IV and CV characteristics were also analyzed to derive a dark current damage factor in InGaAs photodiodes similar to the one proposed by J. R. Srour et al. in silicon devices [6]. Knowing the extension of the depleted volume this damage factor $K_{\text {dark }}$ allows the calculation of the dark current increase due to displacement damage in any InGaAs photodiode. With $\left\langle K_{\text {dark }}\right\rangle=1.2 \times 10^{9} \mathrm{~cm}^{-3} \mathrm{~s}^{-1} \mathrm{MeVg}^{-1}$ we found that InGaAs photodiodes are more than three orders of magnitude more sensitive to displacement damage than silicon-based photodiodes. Additional IV and CV measurements on other InGaAs photodiode references using different irradiation particles of several energies would be of great interest to confirm the universality of the value of $K_{\text {dark }}$ found in this study.

Furthermore, the high sensitivity of InGaAs photodiodes to atomic displacement and the linearity of their dark current increase with the displacement damage dose can be valuable for dosimetry purpose. Indeed, these relatively inexpensive photodiodes will be used more and more often in space especially in optical telecommunication payloads. The periodic measurement of their dark current can be easily carried out and can provide useful data to better characterize the space radiation environment without the necessity of implementing specific on-board dosimeters. Dedicated dosimetry experiments including the characterization of annealing effects would therefore be welcome to characterize the potential of this photodiode technology. 


\section{APPENDIXES}

Irradiation conditions, NIEL values and dark current density increases.

\section{APPENDIX I}

The table below shows the results of the irradiations carried out in this work. All the exposures were made at room temperature with the devices short-circuited. Unless indicated in the last column, the photodiodes were not delidded for the irradiations. The dark current was measured between $20^{\circ} \mathrm{C}$ and $25^{\circ} \mathrm{C}$ using a Keithley picoammeter (model 6485 or 6430). The NIEL values used to plot the data in Fig. 2 are highlighted in bold.

\begin{tabular}{|c|c|c|c|c|c|c|c|c|c|}
\hline Refs. & Manufacturer & $\begin{array}{l}\text { Device } \\
\text { reference }\end{array}$ & $\begin{array}{l}\text { Estimated } \\
\text { photosensitive } \\
\text { area diameter } \\
(\mu \mathrm{m})\end{array}$ & $\begin{array}{l}\text { Particle } \\
\text { type }\end{array}$ & $\begin{array}{l}\text { Energy } \\
(\mathrm{MeV})\end{array}$ & $\begin{array}{l}\text { Total NIEL (elastic + } \\
\text { inelastic) in } \\
\mathrm{In}_{0.53} \mathrm{Ga}_{0.47} \mathrm{As} \\
\left(\mathrm{MeV} . \mathrm{cm}^{2} / \mathrm{g}\right)\end{array}$ & $\begin{array}{l}\text { Fluence } \\
\left(\text { particle } / \mathrm{cm}^{2}\right)\end{array}$ & $\begin{array}{l}\Delta J_{d} \\
(\mathrm{~A} / \mathrm{cm} 2) \\
\text { at }-5 \mathrm{~V}\end{array}$ & Comments \\
\hline \multirow{3}{*}{$\begin{array}{l}\text { This } \\
\text { work }\end{array}$} & \multirow[t]{3}{*}{ Hamamatsu } & \multirow[t]{3}{*}{ G8195 } & \multirow[t]{3}{*}{80} & \multirow[t]{3}{*}{ Protons } & \multirow[t]{3}{*}{60} & \multirow{3}{*}{$\begin{array}{l}3.58 \times 10^{-3}[7] \\
4.00 \times 10^{-3}[8]\end{array}$} & $1 \times 10^{10}$ & $3.21 \times 10^{-6}$ & \multirow{3}{*}{$\begin{array}{l}\text { - The } \\
\text { measurements } \\
\text { were made } 1 \\
\text { month after the } \\
\text { irradiation for the } \\
\text { lowest fluence and } \\
3 \text { months after for } \\
\text { the other ones. }\end{array}$} \\
\hline & & & & & & & $1 \times 10^{11}$ & $2.8 \times 10^{-5}$ & \\
\hline & & & & & & & $1 \times 10^{12}$ & $2.74 \times 10^{-4}$ & \\
\hline \multirow{3}{*}{$\begin{array}{l}\text { This } \\
\text { work }\end{array}$} & \multirow{3}{*}{$\begin{array}{l}\text { II-VI laser } \\
\text { Enterprise }\end{array}$} & \multirow[t]{3}{*}{ PM1R } & \multirow[t]{3}{*}{320} & \multirow[t]{3}{*}{ Protons } & \multirow[t]{3}{*}{60} & \multirow{3}{*}{$\begin{array}{l}3.58 \times 10^{-3}[7] \\
4.00 \times 10^{-3}[8]\end{array}$} & $1 \times 10^{10}$ & $2.16 \times 10^{-6}$ & \multirow{3}{*}{$\begin{array}{l}\text { - The } \\
\text { measurements } \\
\text { were made } 1 \\
\text { month after the } \\
\text { irradiation for the } \\
\text { lowest fluence and } \\
3 \text { months after for } \\
\text { the other ones. }\end{array}$} \\
\hline & & & & & & & $1 \times 10^{11}$ & $2.02 \times 10^{-5}$ & \\
\hline & & & & & & & $1 \times 10^{12}$ & $1.98 \times 10^{-4}$ & \\
\hline \multirow{3}{*}{$\begin{array}{l}\text { This } \\
\text { work }\end{array}$} & \multirow{3}{*}{$\begin{array}{l}\text { GPD } \\
\text { Optoelectronic } \\
\mathrm{s}\end{array}$} & \multirow[t]{3}{*}{ GAP394 } & \multirow[t]{3}{*}{300} & \multirow[t]{3}{*}{ Protons } & \multirow[t]{3}{*}{60} & \multirow{3}{*}{$\begin{array}{l}3.58 \times 10^{-3}[7] \\
4.00 \times 10^{-3}[8]\end{array}$} & $1 \times 10^{10}$ & $3.23 \times 10^{-6}$ & \multirow{3}{*}{$\begin{array}{l}- \text { The } \\
\text { measurements } \\
\text { were made } 1 \\
\text { month after the } \\
\text { irradiation for the } \\
\text { lowest fluence and } \\
3 \text { months after for } \\
\text { the other ones. } \\
\end{array}$} \\
\hline & & & & & & & $1 \times 10^{11}$ & $2.67 \times 10^{-5}$ & \\
\hline & & & & & & & $1 \times 10^{12}$ & $2.98 \times 10^{-4}$ & \\
\hline \multirow{3}{*}{$\begin{array}{l}\text { This } \\
\text { work }\end{array}$} & \multirow[t]{3}{*}{ Lumentum } & \multirow{3}{*}{$\begin{array}{l}\text { EPM605L } \\
\mathrm{L}\end{array}$} & \multirow[t]{3}{*}{55} & \multirow[t]{3}{*}{ Protons } & \multirow[t]{3}{*}{60} & \multirow{3}{*}{$\begin{array}{l}3.58 \times 10^{-3}[7] \\
4.00 \times 10^{-3}[8]\end{array}$} & $1 \times 10^{10}$ & $5.78 \times 10^{-6}$ & \multirow{3}{*}{$\begin{array}{l}\text { - The } \\
\text { measurements } \\
\text { were made } 1 \\
\text { month after the } \\
\text { irradiation for the } \\
\text { lowest fluence and } \\
3 \text { months after for } \\
\text { the other ones. }\end{array}$} \\
\hline & & & & & & & $1 \times 10^{11}$ & $8.37 \times 10^{-5}$ & \\
\hline & & & & & & & $1 \times 10^{12}$ & $6.76 \times 10^{-4}$ & \\
\hline \multirow[t]{3}{*}{$\begin{array}{l}\text { This } \\
\text { work }\end{array}$} & \multirow[t]{3}{*}{ Lumentum } & \multirow[t]{3}{*}{ HRS } & 300 & Protons & 60 & $\begin{array}{l}3.57 \times 10^{-3}[7] \\
\mathbf{4 . 0 0 \times 1 0 ^ { - 3 }}[8]\end{array}$ & $4.3 \times 10^{10}$ & $\begin{array}{l}2.24 \times 10^{-5} \\
1.87 \times 10^{-5} \\
1.47 \times 10^{-5} \\
1.63 \times 10^{-5} \\
1.63 \times 10^{-5} \\
1.37 \times 10^{-5}\end{array}$ & $\begin{array}{l}\text { - The } \\
\text { measurements } \\
\text { were made on-site } \\
\text { soon after the } \\
\text { irradiation. }\end{array}$ \\
\hline & & & & & & & $7.8 \times 10^{10}$ & $\begin{array}{l}3.76 \times 10^{-5} \\
3.11 \times 10^{-5} \\
3.32 \times 10^{-5} \\
3.42 \times 10^{-5} \\
3.53 \times 10^{-5} \\
3.11 \times 10^{-5}\end{array}$ & \\
\hline & & & & & & & $1.3 \times 10^{11}$ & $\begin{array}{l}6.02 \times 10^{-5} \\
4.80 \times 10^{-5} \\
5.64 \times 10^{-5} \\
5.12 \times 10^{-5} \\
5.93 \times 10^{-5} \\
5.14 \times 10^{-5}\end{array}$ & \\
\hline $\begin{array}{l}\text { This } \\
\text { work }\end{array}$ & 3SPhotonics & 1931SGM & 270 & Protons & 30 & $\begin{array}{l}4.23 \times 10^{-3}[7] \\
3.99 \times 10^{-3}[8]\end{array}$ & $5 \times 10^{10}$ & $\begin{array}{l}2.89 \times 10^{-5} \\
2.86 \times 10^{-5}\end{array}$ & $\begin{array}{l}\text { - The } \\
\text { measurements }\end{array}$ \\
\hline & & & & & & & $1 \times 10^{11}$ & $5.3 \times 10^{-5}$ & were made on-site \\
\hline
\end{tabular}




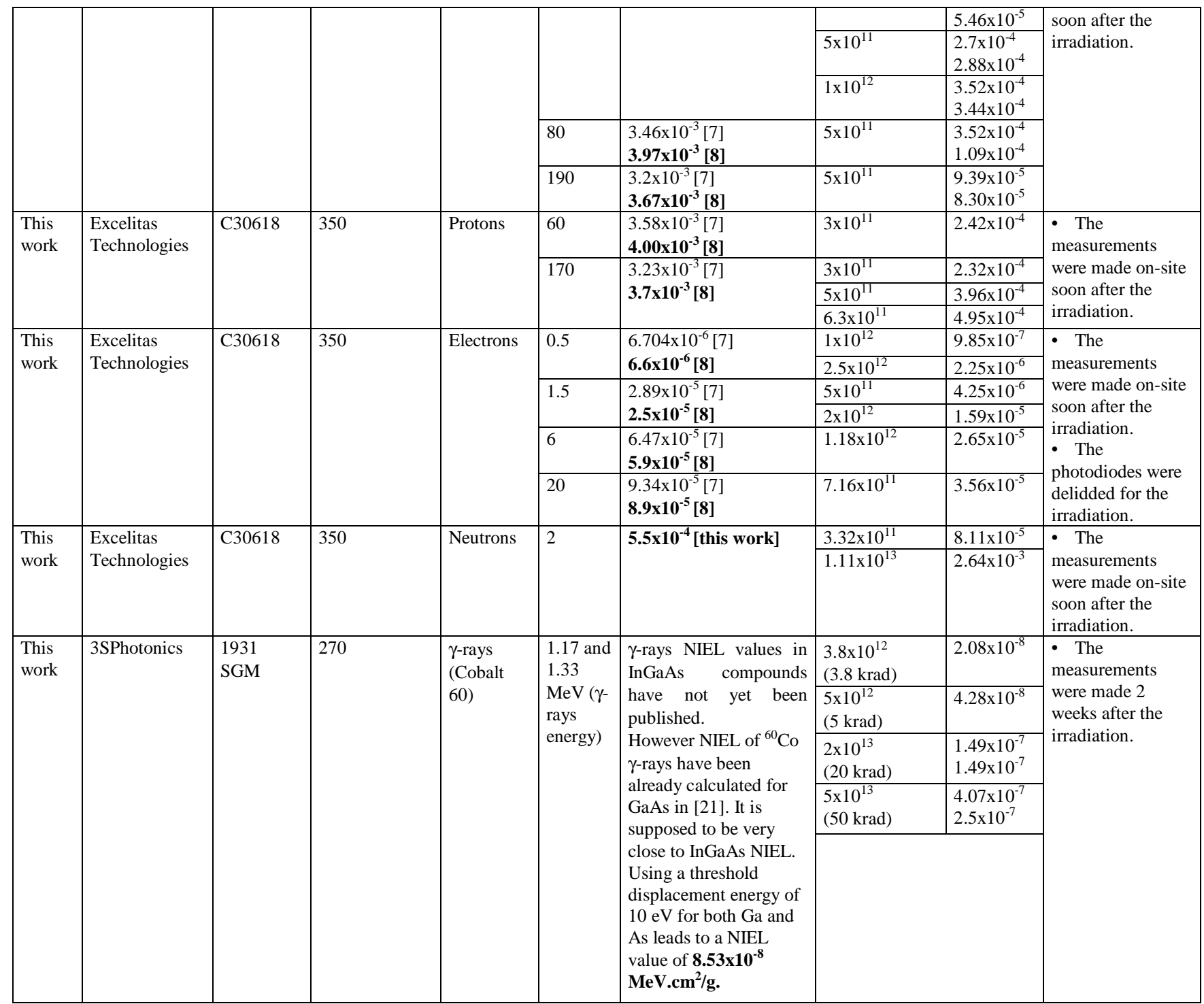

\section{APPENDIX II}

The table below gives an overview of the results already published in the literature. All the available information regarding either the irradiation or the measurement conditions has been reported in the last column. The NIEL values used to plot the data in Fig. 2 are highlighted in bold.

\begin{tabular}{|c|c|c|c|c|c|c|c|c|c|}
\hline Refs. & Manufacturer & $\begin{array}{l}\text { Device } \\
\text { reference }\end{array}$ & $\begin{array}{l}\text { Estimated } \\
\text { photosensiti } \\
\text { ve area } \\
\text { diameter } \\
(\mu \mathrm{m})\end{array}$ & $\begin{array}{l}\text { Particle } \\
\text { type }\end{array}$ & $\begin{array}{l}\text { Energy } \\
(\mathrm{MeV})\end{array}$ & $\begin{array}{l}\text { Total NIEL (elastic }+ \\
\text { inelastic) in } \\
\mathrm{In}_{0.53} \mathrm{Ga}_{0.47} \mathrm{As} \\
\left(\mathrm{MeV} \cdot \mathrm{cm}^{2} / \mathrm{g}\right)\end{array}$ & $\begin{array}{l}\text { Fluence } \\
\left(\text { particle } / \mathrm{cm}^{2}\right)\end{array}$ & $\begin{array}{l}\Delta J_{d} \\
(\mathrm{~A} / \mathrm{cm} 2)\end{array}$ & Comments \\
\hline \multirow[t]{5}{*}[10]{} & \multirow[t]{5}{*}{ Mitsubishi } & \multirow[t]{5}{*}{ PD7006 } & \multirow[t]{5}{*}{300} & \multirow[t]{5}{*}{ Protons } & 5 & $\begin{array}{l}1.22 \times 10^{-2}[7] \\
\mathbf{1 . 1 2} \times 10^{-2}[8]\end{array}$ & $5 \times 10^{10}$ & $1.11 \times 10^{-4}$ & \multirow{5}{*}{$\begin{array}{l}\text { - The } \\
\text { photodiodes were } \\
\text { delidded for tests } \\
\text { with proton } \\
\text { energies below } 40 \\
\text { MeV. }\end{array}$} \\
\hline & & & & & 10 & $\begin{array}{l}7.02 \times 10^{-3}[7] \\
6.5 \times 10^{-3}[8]\end{array}$ & $5 \times 10^{10}$ & $6.44 \times 10^{-5}$ & \\
\hline & & & & & 15 & $\begin{array}{l}5.49 \times 10^{-3}[7] \\
\mathbf{4 . 9} \times 10^{-3}[8]\end{array}$ & $5 \times 10^{10}$ & $4.85 \times 10^{-5}$ & \\
\hline & & & & & 30 & $\begin{array}{l}4.23 \times 10^{-3}[7] \\
\mathbf{3 . 9 9} \times 10^{-3}[8]\end{array}$ & $5 \times 10^{10}$ & $3.95 \times 10^{-5}$ & \\
\hline & & & & & 60 & $\begin{array}{l}3.58 \times 10^{-3}[7] \\
4.00 \times 10^{-3}[8]\end{array}$ & $5 \times 10^{10}$ & $3.96 \times 10^{-5}$ & \\
\hline
\end{tabular}




\begin{tabular}{|c|c|c|c|c|c|c|c|c|c|}
\hline$[1]$ & Discovery & DSC30 & 30 & Protons & 35 & $\begin{array}{l}4.04 \times 10^{-3}[7] \\
3.9 \times 10^{-3}[8]\end{array}$ & $\begin{array}{l}9.3 \times 10^{10} \\
1.85 \times 10^{11} \\
2.78 \times 10^{11}\end{array}$ & $\begin{array}{l}1.12 \times 10^{-4} \\
1.32 \times 10^{-4} \\
1.23 \times 10^{-4} \\
2.46 \times 10^{-4} \\
1.47 \times 10^{-4} \\
3.66 \times 10^{-4}\end{array}$ & $\begin{array}{l}\text { - The } \\
\text { photodiodes were } \\
\text { not delidded for } \\
\text { the irradiation. } \\
\text { - The } \\
\text { photodiodes were } \\
\text { biased at }-2 \mathrm{~V} \\
\text { during the } \\
\text { irradiation. } \\
\text { - The } \\
\text { measurements } \\
\text { were made on-site } \\
\text { soon after the } \\
\text { irradiation. } \\
\text { - The dark } \\
\text { current was } \\
\text { measured at }-2 \mathrm{~V} \text {. }\end{array}$ \\
\hline \multirow[t]{10}{*}{ [2] } & \multirow[t]{10}{*}{ Atmel } & \multirow[t]{10}{*}{$\begin{array}{l}\text { Spot } 4 \text { MIR } \\
\text { detector }\end{array}$} & \multirow[t]{10}{*}{$\begin{array}{l}22 \mu \mathrm{m} \times 45 \\
\mu \mathrm{m}\end{array}$} & \multirow[t]{10}{*}{ Protons } & 9.1 & $\begin{array}{l}7.5 \times 10^{-3}[7] \\
6.9 \times 10^{-3}[8]\end{array}$ & $2 \times 10^{9}$ & $9.55 \times 10^{-7}$ & \multirow{10}{*}{$\begin{array}{l}\text { The devices } \\
\text { were irradiated } \\
\text { unbiased. } \\
\text { - Measurements } \\
\text { have been carried } \\
\text { out at } 5^{\circ} \mathrm{C} \text {; the } \\
\text { dark current was } \\
\text { extrapolated at } \\
25^{\circ} \mathrm{C} \text { using the } \\
0.44 \mathrm{eV} \text { activation } \\
\text { energy given in } \\
\text { [2]. } \\
\text { - The dark } \\
\text { current was } \\
\text { measured at }-1 \mathrm{~V} \text {. }\end{array}$} \\
\hline & & & & & \multirow[t]{2}{*}{10.55} & $7.01 \times 10^{-3}[7]$ & $3 \times 10^{8}$ & $1.43 \times 10^{-7}$ & \\
\hline & & & & & & & $2 \times 10^{9}$ & $1.11 \times 10^{-6}$ & \\
\hline & & & & & 17 & $\begin{array}{l}5 \times 10^{-3}[7] \\
4.5 \times 10^{-3}[8]\end{array}$ & $\frac{2 \times 10^{9}}{1 \times 10^{10}}$ & $\frac{6.36 \times 10^{-7}}{3.98 \times 10^{-6}}$ & \\
\hline & & & & & 35.8 & $\begin{array}{l}4.02 \times 10^{-3}[7] \\
\mathbf{3 . 8 9} \times 10^{-3}[8]\end{array}$ & $2 \times 10^{9}$ & $6.36 \times 10^{-7}$ & \\
\hline & & & & & \multirow[t]{2}{*}{63.5} & \multirow{2}{*}{$\begin{array}{l}3.55 \times 10^{-3}[7] \\
3.99 \times 10^{-3}[8]\end{array}$} & $2 \times 10^{9}$ & $5.09 \times 10^{-7}$ & \\
\hline & & & & & & & $1 \times 10^{10}$ & $3.18 \times 10^{-6}$ & \\
\hline & & & & & 100 & $\begin{array}{l}3.39 \times 10^{-3}[7] \\
\mathbf{3 . 9 3}^{-9} \times 10^{-3}[8]\end{array}$ & $1 \times 10^{10}$ & $1.43 \times 10^{-6}$ & \\
\hline & & & & & 200 & $\begin{array}{l}3.17 \times 10^{-3}[7] \\
\text { 3. } 66 \times 10^{-3}[8]\end{array}$ & $1 \times 10^{10}$ & $2.86 \times 10^{-6}$ & \\
\hline & & & & & 300 & $\begin{array}{l}3.14 \times 10^{-3}[7] \\
\text { 3. } 66 \times 10^{-3}[8]\end{array}$ & $1 \times 10^{10}$ & $1.67 \times 10^{-6}$ & \\
\hline \multirow[t]{4}{*}{ [11] } & \multirow[t]{4}{*}{ Hamamatsu } & \multirow{4}{*}{$\begin{array}{l}\text { G6849-01 } \\
\text { (quadrant- } \\
\text { type) }\end{array}$} & \multirow[t]{4}{*}{1000} & \multirow[t]{4}{*}{ Protons } & \multirow[t]{4}{*}{\begin{tabular}{|l|}
105 \\
\end{tabular}} & \multirow{4}{*}{$\begin{array}{l}3.39 \times 10^{-3}[7] \\
\mathbf{3 . 9 1 \times 1 0 ^ { - 3 }}[\mathbf{8}]\end{array}$} & $5 \times 10^{9}$ & $3.26 \times 10^{-6}$ & \multirow{4}{*}{$\begin{array}{l}\quad \text { The } \\
\text { measurements } \\
\text { were made on-site } \\
\text { soon after the } \\
\text { irradiation. }\end{array}$} \\
\hline & & & & & & & $1.5 \times 10^{10}$ & $1.20 \times 10^{-5}$ & \\
\hline & & & & & & & $3.3 \times 10^{10}$ & $2.87 \times 10^{-5}$ & \\
\hline & & & & & & & $8 \times 10^{10}$ & $8.04 \times 10^{-5}$ & \\
\hline
\end{tabular}




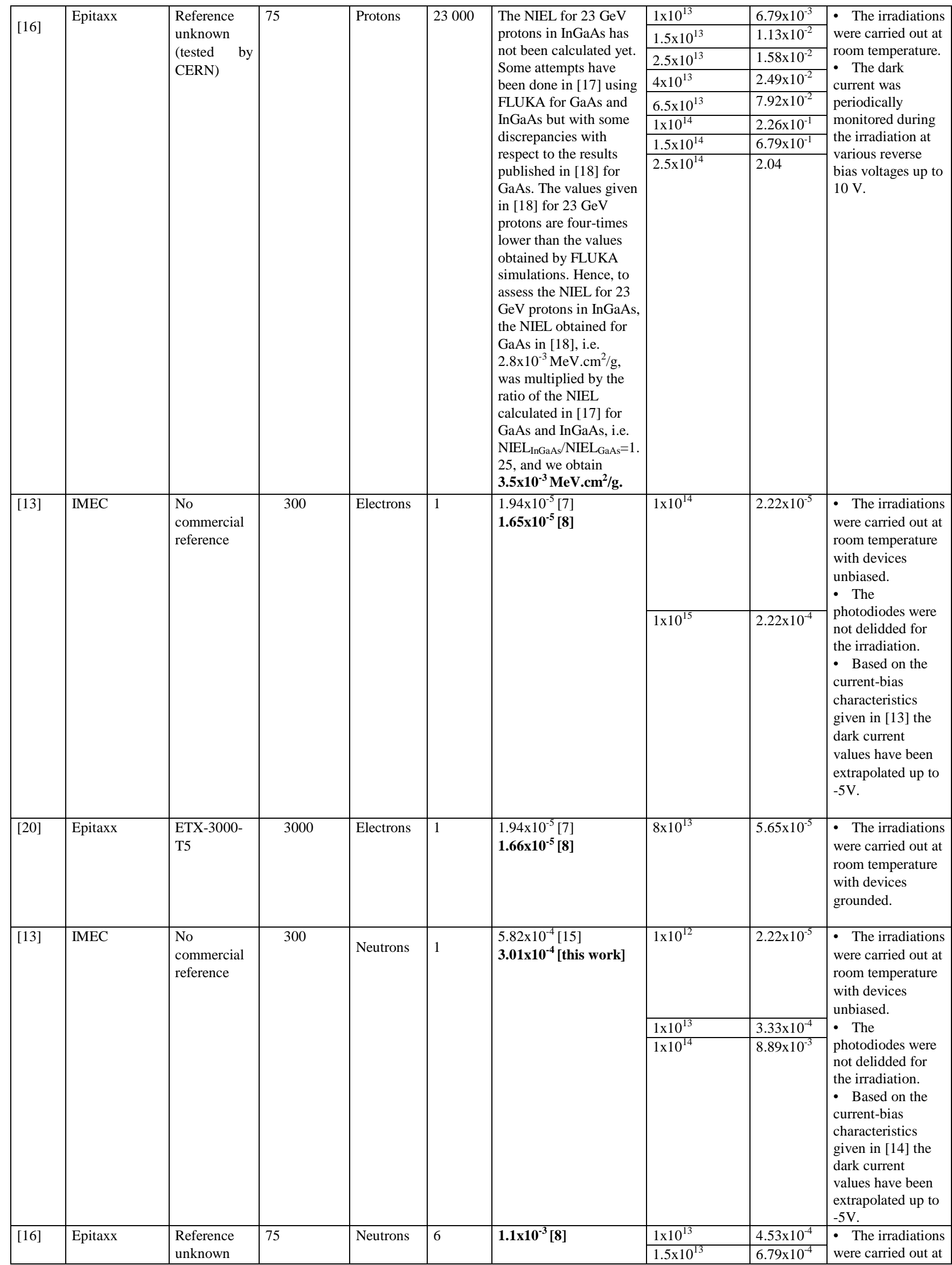




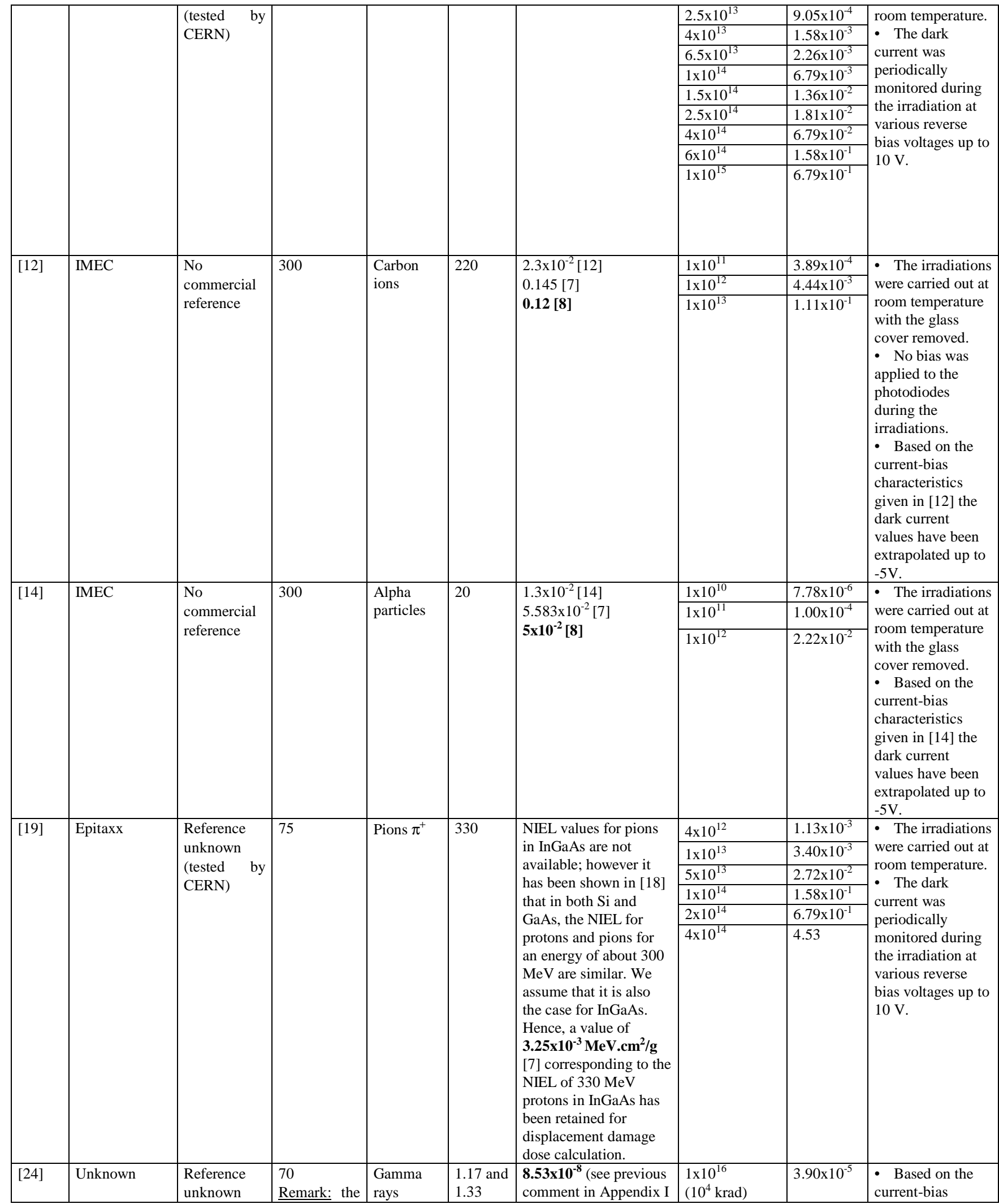




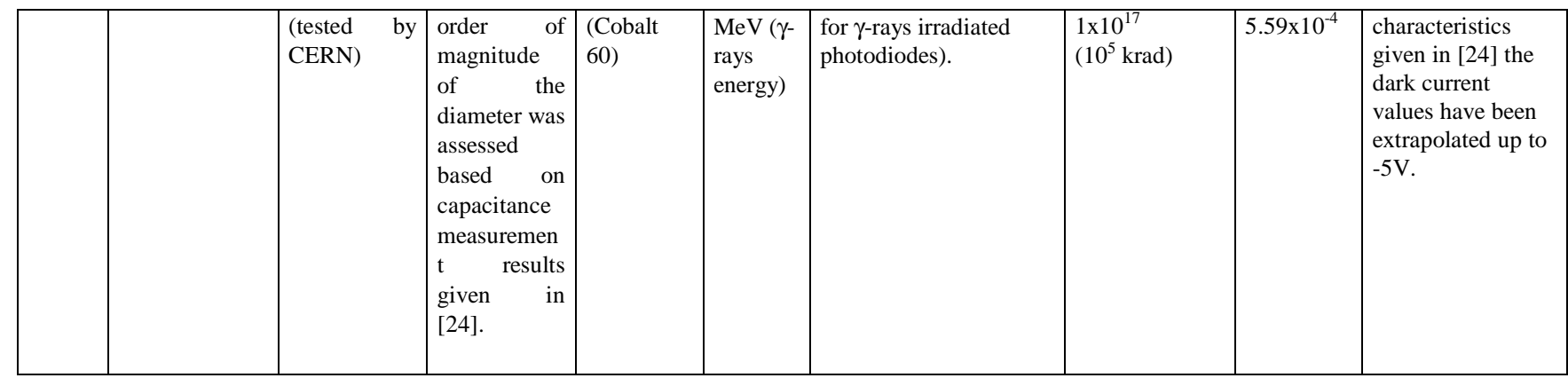

\section{ACKNOWLEDGEMENT}

This work was partially supported by the ROVER project of the European Defense Agency under grant number RF 122535.

\section{REFERENCES}

[1] A. M. Joshi, F. Heine, T. Feifel, "Rad-hard ultrafast InGaAs photodiodes for space applications", in Proc. SPIE 6220, Spaceborne Sensors III, May 2006, (doi : 10.1117/12.666055).

[2] S. Barde, E. Ecoffet, J. Costeraste, A. Meygret and X. Hugon, "Displacement Damage Effects in InGaAs Detectors : Experimental Results and Semi-Empirical Model Prediction”, IEEE Trans. Nucl. Sci., vol. 47 , no. 6, pp. 2466-2472, Dec. 2000.

[3] L. Tauziède, K. Beulé, M. Boutillier, F. Bernard, J.L. Reverchon, A. Buffaz, "Evaluation of InGaAs array detector suitability to space environment", in Proc. International Conference on Space Optics (ICSO), 2012, (doi: 10.1117/12.2309217).

[4] S. Rougelot, S. Mariojouls, T. Buret, D. Ramecourt, et X. Calmet, "Procurement and qualification of optical components for space fibre optic gyroscope application", in Proc. Int. Symp. on Reliability of Optoelectronics for Space ISROS 2009, pp. 231-236.

[5] G. Pedroza, M. Boutillier, L.S. How, L. Béchou, T. Nuns, P. Arnolda, Y. Ousten, "Proton irradiation effects on InGaAs/InP photodiodes for space applications", in Proc. IEEE 13th Eur. Conf. Radiation and Its Effects on Components and Systems (RADECS 2012), 2012.

[6] J. R. Srour and D. H. Lo, "Universal Damage Factor for RadiationInduced Dark Current in Silicon Devices", IEEE Trans. Nucl. Sci., vol. 47, no. 6, pp. 2451-2459, Dec. 2000.

[7] www.sr-niel.org

[8] C. Inguimbert, and R. Gigante, "NEMO: A code to compute NIEL of protons, neutrons, electrons, and heavy ions," IEEE Trans. Nucl. Sci., vol. 53, no. 4, pp. 1967-1972, Aug. 2006.

[9] OMERE : Outil de Modélisation de l'Environnement Radiatif Externe, version 4.2. [Online]. Available:http://www.trad.fr/OMERE-14.html

[10] P. W. Marshall and C. J. Dale, "Space radiation effects on optoelectronic materials and components for $1300 \mathrm{~nm}$ fiber optic data bus”, IEEE Trans. Nucl. Sci., vol. 39, no. 6, pp. 1982-1989, Dec. 1992.

[11] R. Aniceto, R. Milanowski, S. Moro, K.Cahoy, and G. Schlenvogt, "Proton radiation effects on Hamamatsu InGaAs PIN photodiodes", in Proc. RADECS 2017, Geneva, Switzerland, 02-06 Oct. 2017.

[12] T. Kudou, H. Ohyama, E. Simoen, C. Claeys, Y. Takami, K. Shigaki, A. Fuji and H. Sunaga, "Radiation damage of InGaAs photodiodes by high energy particles”, Mat. Res. Soc. Proc. Vol. 487, pp. 471-476, 1998.

[13] H. Ohyama, J. Vanhellemont, Y. Takami, K. Hayama, T. Kudou, S. Kohiki, H. Sunaga and T. Hakata, "Degradation of InGaAs pin photodiodes by neutron irradiation”, Semicond. Sci. Technol., Vol. 11, pp. 1461-1463, 1996.

[14] H. Ohyama, E. Simoen, C. Claeys, Y. Takami, T. Kudou and H. Sunaga, "Radiation source dependence of degradation and recovery of irradiated In0.53Ga0.47As PIN photodiodes", in Proc. IEEE 4th Eur. Conf. Radiation and Its Effects on Components and Systems (RADECS 1997), pp. 108-113, 1997.
[15] A. Shatalov, S. Subramanian and A. Klein, "Correlation between nonionizing energy loss and the offset voltage shift in InP-InGaAs heterojunction bipolar transistor", IEEE Trans. Nucl. Sci., vol. 48, no. 6, pp. 2262-2269, Dec. 2001

[16] K. Gill, V. Arbet-Engels, J. Batten, G. Cervelli, R. Grabit, C. Mommaert, G. Stefanini, J. Troska, F. Vasey, "Radiation damage studies of optoelectronic components for the CMS tracker optical links", in Proc. IEEE 4th Eur. Conf. Radiation and Its Effects on Components and Systems (RADECS 1997), 1997, pp. 405-412.

[17] P. Stejskal, "Radiation effects in optical link componenets for future particle physics detectors", PhD thesis, CERN, 2013.

[18] A. Chilingarov, J.S. Meyer and T. Sloan, "Radiation damage due to NIEL in GaAs particle detectors", Nuclear Instruments and Methods in Physics Research A, 395, 1997, pp. 35-44.

[19] K. Gill, C. Aguilar, C. Azvedo, V. Arbets-Engels, J. Batten, G. Cervelli, R. Grabit, F. Jensen, C. Mommaert, J. Troska and F. Vasey, "Radiation damage studies of optical link components for applications in future high energy physics experiments", in Proc. SPIE 3440, Photonics for space environments VI, Oct. 1998, (doi: 10.1117/12.326686).

[20] G.J. Shaw, S.R. Messenger, R.J. Walters, and G.P. Summers, "Radiation-induced reverse dark currents in $\mathrm{In}_{0.53} \mathrm{Ga}_{0.47}$ As photodiodes", J. Appl. Phys. 73(11), pp. 7244-7249, June 1993.

[21] E. EL Allam, C. Inguimbert, T. Nuns, A. Meulemberg, A. Jorio, I. Zorkani, "Gamma and Electron NIEL Dependence of Irradiated GaAs," IEEE Trans. Nucl. Sci., vol. 64, no. 3, pp. 991-998, Mar. 2017.

[22] A. Akkerman, J. Barak, M.B. Chadwick, J. Levinson, M. Murat, Y. Lifshitz, "Updated NIEL calculations for estimating the damage induced by particles and $\gamma$-rays in $\mathrm{Si}$ and GaAs", Radiation Physiscs and Chemistry (62), pp. 301-310, 2001.

[23] https://physics.nist.gov/PhysRefData/XrayMassCoef/tab3.html

[24] S. Seif El Nasr-Storey, S. Detraz, L. Olantera, C. Sigaud, C. Soos, J. Troska, and F. Vasey, "High dose gamma irradiation of lasers and p-i-n photodiodes for HL-LHC data transmission applications", IEEE Trans. Nucl. Sci., vol. 60, no. 4, pp. 2518-2524, Aug. 2013.

[25] B. Efron, "Bootstrap methods: another look at the jackknife", The Annals of Statistics, Vol. 7, N¹, pp.1-26, 1979. 